\title{
AC 2008-688: RECRUITMENT IN ENGINEERING/TECHNOLOGY TEACHER EDUCATION: FACTORS THAT INFLUENCE FEMALES
}

Kara Harris, College of Technology - Purdue University 


\section{Recruitment and Retention in Engineering/Technology Teacher Education: Factors that Influence Females}

It is not breaking news that there is an under representation of females in Science, Technology, Engineering, and Mathematic (STEM) disciplines nationwide (National Academy of Engineering, 2004). In fact, studies indicate that enrollment (both male and female) in Engineering/Technology Teacher Education (ETTE) programs have been on a downward spiral for decades ${ }^{4,2,6,11,12}$. This decline has not only had a direct affect on the number of highly qualified engineering/technology education teachers that are available to teach in public schools, but has also affected enrollment in technology teacher education programs at colleges/universities across the nation. This decline, if not properly addressed, could lead to the demise of engineering/technology education programs at the secondary and post-secondary level.

Successful efforts have been set forth in many areas of the discipline, such as curriculum. Wright and Custer (1998) stated that, "Technology education professionals have spent a great deal of time and energy focused on defining the mission of technology education and redefining the curriculum. However, the profession has made only limited efforts at recruiting students into technology education teacher preparation programs." (p. 58) This lack of effort and collaboration could be due to confusion as to who's responsibility it is to recruit these teachers. According to Starkweather, (1999)

It is difficult to get everyone in our field to understand that the critical shortage of teachers is a problem for all of us. Classroom teachers often think that the problem is for universities and many university personnel are not willing to put forth the effort required to recruit a sufficient number of prospective teachers. There are many other perspectives on the issue. The bottom line is that recruitment of prospective technology education teachers is everyone's problem. It is a problem that requires considerable attention by educators at all levels. The challenge will be to get enough qualified technology teachers in the workforce to continue to move the profession forward and thus avoid having programs either closed or staffed by unqualified teachers. (p.27) ${ }^{5}$

According to the Indiana Department of Education, there are currently 1044 ETTE teachers in Indiana. Of the 1044 ETTE teachers only 56 are female (5\%). ${ }^{3}$ Although nationwide data pertaining to the number of practicing ETTE teachers is not available, if one were to estimate the number of females teaching in the profession based upon Indiana's statistics females are grossly underrepresented.

But how does one increase the number of females teaching in ETTE? Or what type of recruitment activities or motivators would be effective in attracting females to the ETTE profession? According to Shanahan (2006):

The secret to increasing females in technology is not to "fix" the girls but to make the technology classroom and profession more appealing to and welcoming of girls. Rather than trying to replicate the approaches 
and interests of the small number of girls successful in technology to a larger group, the secret is to make the environment one that the larger group wishes to join. (p. 22) ${ }^{10}$

Shanahan (2006) further stated that having role models that females could identify with, such as other females, could also be a factor in recruitment. With very few females in the profession there are few role models with whom young women can identify. ${ }^{10}$

One must remember that the key to effective recruitment is to understand what influences the individuals one is trying to motivate. In a recent National Science Foundation (NSF) funded project, Extraordinary Women Engineers (2005) stated that:

Professional interests for high school girls hinge upon relevance.

Relevance incorporates that a job is rewarding, and it suggests that the profession is for someone "like me." Girls want their future job to be enjoyable, have a good working environment, make a difference, offer a good salary, and be flexible. (p.12) ${ }^{8}$

With this obvious need present to recruit individuals into ETTE, specifically females and an understanding of what motivates young women to choose certain career paths, the researcher has identified specific factors that influenced females to choose ETTE as a career path.

\section{Research Questions}

1. What are the basic demographic data of females pursuing degrees in ETTE in the United States?

2. What factors influenced females to peruse degrees in ETTE?

\section{Methodology}

This study was conducted in the fall semester of 2007 at Purdue University and was based upon previous work conducted by Wright \& Custer (1998) and Gray \& Daugherty 4,13 . After completing a thorough literature review and speaking with multiple secondary engineering/technology education teachers, pre-service engineering/technology education teachers, university professors, and other professionals who work directly with engineering/technology education the researcher created a survey instrument that examined different aspects of recruitment and retention in ETTE. The instrument was then validated by university faculty at Purdue University, Indiana State University, Ball State University, and Central Missouri University $(n=5)$, university students at Purdue University $(n=34)$, classroom teachers in Indiana $(n=5)$, and other professionals in technology education $(n=3)$.

The survey (Appendix A) covered basic demographic information such as, which engineering/technology education courses and extra-curricular activities the students participated in during high school. In addition, the survey instructed students to rate on a four-point scale which factors influenced them to pursue degrees in engineering/technology education, and which factors encouraged them to remain in 
engineering/technology education. The four-point scale was divided into categories of absolutely no influence, somewhat influenced, highly influenced and strongly influenced.

The researcher used the Industrial Teacher Education Directory (2007) to select the sample population. The researcher contacted (via telephone) faculty working in ETTE programs at all universities in the Industrial Teacher Education Directory (2007) to inform them of the research project and to ask for their participation by administering the survey instruments to their ETTE students. Of the universities listed in the directory the researcher was able to make contact with a faculty member at 52 universities-the ETTE students at these universities were used as the sample population. A packet was then mailed in October of 2007 to each university and contained a cover letter explaining the proper procedures for administering the survey to all of their students, cover letter to students explaining the study, survey instrument, and return postage envelope. Of the 52 universities that received the packet 32 responded for a response rate of $60 \%$. Universities who chose to participate were Millersville University, New York College at Buffalo, Old Dominion University, Georgia Southern University, California Pennsylvania University, University of Wisconsin-Stout, Millersville University, Utah State University The Ohio State University, Clemson University, Eastern Illinois University, University of Georgia, Kent State University, Pittsburg State University, University of Minnesota, South Carolina State University, University of WisconsinPlatteville, Wayne State University, Fort Hayes State University, St. Cloud University, North Carolina State University, Bemidji State University, The College of New Jersey, Ohio Northern University, Illinois State University, St. Petersburg College, University of Nebraska, Oswego University, Utah State University, Georgia Southern University, Purdue University, Ball State University, California University of Pennsylvania, and Indiana State University. Of the 52 universities that responded to the survey 530 total students responded. Of the 530 student responses 69 were from female students.

\section{Findings}

Demographic Information

Participants were asked to describe their demographic characteristics for the study. Demographic information that was collected for this study was class rank, age, and ethnicity, Figure One illustrates the class standing of participants. Of the 59 female participants $4(7 \%)$ were classified themselves freshman, six (10\%) were classified as sophomores, 17 (29\%) as juniors, $26(44 \%)$ classified themselves as seniors, and six $(10 \%)$ were classified as graduate students. 
Figure 1

Class rank of female participants. $(N=59)$

\begin{tabular}{|l|l|l|}
\hline Class rank of female participants $(\mathbf{N}=59)$ & $\mathbf{n}$ & $\mathbf{\%}$ \\
\hline Freshman & 4 & $7 \%$ \\
\hline Sophomore & 6 & $10 \%$ \\
\hline Junior & 17 & $29 \%$ \\
\hline Senior & 26 & $44 \%$ \\
\hline Graduate & 6 & $10 \%$ \\
\hline
\end{tabular}

Participants were also asked to indicate their age at the time of the study. The age of participants can be found in graphic form in figure 2. Eighteen or (31\%) of participants were from ages $18-20,23$ or (39\%) indicated that they were ages $21-23$, nine (18\%) were ages $24-26$, and nine (18\%) were over the age of 26.

Figure 2

Indicates Age of female participants. $(N=59)$

\begin{tabular}{|l|l|l|}
\hline Age of female participants $(\mathbf{N = 5 9})$ & $\mathbf{n}$ & $\mathbf{\%}$ \\
\hline $\mathbf{1 8 - 2 0}$ years of age & 4 & $31 \%$ \\
\hline $21-23$ years of age & 6 & $39 \%$ \\
\hline $24-26$ years of age & 17 & $15 \%$ \\
\hline Over 26 years of age & 26 & $15 \%$ \\
\hline
\end{tabular}

The ethnic make-up of participants varied among Caucasian, African American, Asian American, Hispanic American, Native American, and Persian decent. Of the 59 participants $45(76 \%)$ indicated they were Caucasian, $6(10 \%)$ were Hispanic American, 4 (7\%) described themselves as African American, $3(5 \%)$ indicated they were Asian American, and 1 (2\%) was of Persian decent.

Figure 3

Indicates ethnicity of female participants. $(N=69)$

\begin{tabular}{|l|l|l|}
\hline Ethnicity of female participants (N=59) & $\mathbf{n}$ & $\mathbf{\%}$ \\
\hline Caucasian & 45 & $76 \%$ \\
\hline Hispanic American & 6 & $10 \%$ \\
\hline African American & 4 & $7 \%$ \\
\hline Asian American & 3 & $5 \%$ \\
\hline Persian American & 1 & $2 \%$ \\
\hline
\end{tabular}

\section{Factors that Influence Females}

Respondents were asked to rate to what degree certain factors influenced their decisions to purse degrees in technology education. Figure 4 illustrates some of the 
factors that did and did not appear to influence a student's decision to pursue a degree in ETTE at the post-secondary level. Of the 16 factors that were rated only one was rated as a 3.0 or above on a 4.0 scale. The top rated factor was personal interest or hobby with a mean rating of 3.14. The second highest rated influence was past experience in a technology education course with a mean rating of 2.55. High school teacher was the third most influential factor with a mean rating of 2.53. Parents or guardians were rated as the forth highest factor influencing females to enter into degrees in ETTE with a mean of 2.28. Information about the major from a student who was currently pursuing the degree area rated as the fifth highest factor with a mean rating of 2.0 on a 4.0 scale. No other factor rated above a 2.0 on the 4.0 scale.

\section{Figure 4}

Indicates factors that influenced students when choosing college major. $(N=59)$

\begin{tabular}{lc}
\hline Factor & Mean \\
\hline Personal interests or hobbies & 3.14 \\
Past experiences in technology education courses & 2.55 \\
High school or middle school teacher & 2.53 \\
Parents or guardians & 2.28 \\
Information from student who was majoring in technology education & 2.00 \\
University faculty & 1.83 \\
Relatives who are not my parents or sibling & 1.69 \\
College friend & 1.68 \\
High school friend & 1.47 \\
Past experiences in technology education extra curricular activities & 1.41 \\
University Engineering/Technology Teacher Education web site & 1.37 \\
Mass media & 1.32 \\
Athletic coach & 1.28 \\
Brother or sister & 1.21 \\
High school guidance counselor & \\
Visit to my high school from University & \\
High School Principal & \\
Conclusions and Recommendations & According to the results of the research project, there are approximately 59 females \\
pursuing degrees in ETTE across the nation. Based upon those numbers, it can be \\
concluded that females make-up only 11\% of the pre-service engineering/technology \\
education teacher population in the United States. This is only a slight increase in \\
females in the field when compared to a similar study conducted by Wright and Custer \\
(1998). Wright and Custer indicated 12.2\% of the undergraduate ETTE population was \\
female in 1998. This is a discouraging drop in the female population when one \\
considers the amount of research that has been conducted in gender equity over the past \\
10 years. It is apparent that more effective work needs to be done in regard to female \\
recruitment in ETTE.
\end{tabular}

Only one factor was listed as having a strong influence in females' decisions to enter into ETTE. Personal interests or a hobby, with a mean of 3.14, was the highest rated 
influential factor among females entering into ETTE. In addition to this, past experiences in technology education courses, high school or middle school teachers, parents or guardians, and information from a student who was majoring in technology education rated as somewhat influential (2.0 or above) in their decisions to pursue degrees in ETTE.

The researcher recommends that professionals consider the work of both the Extraordinary Engineers Project ${ }^{8}$ and the work of Shanahan ${ }^{10}$ in conjunction with the findings of this study when recruiting females into the profession. According to the data from this study, females appear to be most influenced by their own personal interests when choosing ETTE as a career path. In addition Shanahan suggested instead of trying to fix the girls make the classroom/laboratory environment more conducive and welcoming of females. Furthermore, the Extraordinary Engineers Project indicated that females desire a career that is flexible, will allow them to make a difference, enjoyable, has a good working environment, and has a good income.

When talking with perspective female engineering/technology teachers it may be advantageous to relate her personal interests or hobbies to many of the attributes of teaching engineering/technology education such as how it will allow them to make a difference, the good work environment, its flexibility and time off, and how it will allow them to make a difference in the lives of many young people. In addition, making the laboratory and classroom environment a gender neutral environment may also help them to banish any "male dominated" pre-conceptions they may have.

Although this study revealed some points of interest in recruiting females into the ETTE classroom, there are still many facets that could be explored more in depth. The researcher recommends that this study be repeated at a later time using the nationwide population of females, surveying current females in the field to gain their perceptions of attracting females into the profession, conducting a survey to gain an accurate count of the number of females that are currently teaching engineering/technology education in the U.S., and create a teacher mentoring program for females at the secondary level so they can be aware of the opportunities they have in teaching engineering/technology education. 
Appendix A:

$\underline{\text { Survey Instrument }}$ 


\section{Engineering/Technology Teacher Education Recruitment Survey}

\section{SECTION I - Demographic Information}

Directions: Please indicate which of the following best describes your demographic information.

1. What is your current class standing?

Freshman

Sophomore

Junior

Senior

Graduate Student

2. What is your current age?

$18-20$

$21-23$

24-26

Over 26

3. What is your gender?

Male

Female

4. How do you define your ethnicity?

African American

Asian American

Caucasian

Hispanic American

Native American

Other (please specify)

5. Please list the primary occupation of your father or male guardian on the line below.

6. Please list the primary occupation of your mother or female guardian on the line below. 


\section{Engineering/Technology Teacher Education Recruitment Survey}

\section{SECTION II - Recruitment and Retention}

Directions: Please indicate which of the following best describes your experiences in engineering/technology teacher education.

7. Did you choose Engineering/Technology Teacher Education as your college major as an incoming freshman? If you answer no, please go to number 8 . If you answer yes, please go to number 9.

Yes $\quad$ No

8. If Engineering/Technology Teacher Education was NOT your first college major, please list the major or majors you studied prior to switching to Engineering/Technology Education on the below.

9. Which of the following courses were you enrolled in during high school?

\section{Technology Education}

Communications

Manufacturing

Construction

Transportation/Power and Energy

Bio Technology

Engineering

Drafting/CAD

Other

None
Project Lead the Way

Introduction to Engineering Design

Principles of Engineering

Civil Engineering \& Architecture

Computer Integrated

Manufacturing

Digital Electronics

Aerospace

Engineering Design \&

Development

Bio Technical Engineering

Other

None

10. Which of the following extra-curricular or course related activities did you participate in during middle school and/or high school? Please check all that apply.

Sports

FIRST Robotics

LEGO League

Super High Mileage Challenge/Solar Vehicle Challenge

Boys Club/Girls Club/YMCA/YWCA

4-H

Scouting (Boy Scouts, Eagle Scouts, or Girl Scouts)

Technology Student Association (TSA)

Future Farmers of America (FFA)

Skills USA

Academic Teams (BETA Club, Spell Bowl, Quiz Bowl)

None

Other 


\section{Engineering/Technology Teacher Education Recruitment Survey}

Directions: Please indicate, by checking the appropriate box below, to what degree each of the following items influenced your decision to become an Engineering/Technology Education Teacher.

\begin{tabular}{|l|l|l|l|l|}
\hline $\begin{array}{c}\text { Which factors influenced } \\
\text { you to pursue this major? }\end{array}$ & $\begin{array}{c}\text { Absolutely } \\
\text { No } \\
\text { Influence }\end{array}$ & $\begin{array}{c}\text { Somewhat } \\
\text { Influenced }\end{array}$ & $\begin{array}{c}\text { Highly } \\
\text { Influenced }\end{array}$ & $\begin{array}{c}\text { Strongly } \\
\text { Influenced }\end{array}$ \\
\hline $\begin{array}{l}\text { Visit to my high school from the } \\
\text { university }\end{array}$ & & & & \\
\hline University faculty & & & \\
\hline $\begin{array}{l}\text { Mass media (recruitment videos, } \\
\text { flyers, and/or pamphlets) }\end{array}$ & & & \\
\hline $\begin{array}{l}\text { University } \\
\text { Engineering/Technology } \\
\text { Teacher Education web site }\end{array}$ & & & \\
\hline $\begin{array}{l}\text { Information about the major } \\
\text { from a student who was } \\
\text { majoring in } \\
\text { engineering/technology teacher } \\
\text { education }\end{array}$ & & & \\
\hline $\begin{array}{l}\text { Past experiences in technology } \\
\text { education courses }\end{array}$ & & & \\
\hline $\begin{array}{l}\text { Past experiences in technology } \\
\text { education extra-curricular or co- } \\
\text { curricular activities. TSA, } \\
\text { FIRST Robotics, LEGO League, } \\
\text { Skills USA, } \text { tc. }\end{array}$ & & & & \\
\hline $\begin{array}{l}\text { High school or middle school } \\
\text { teacher }\end{array}$ & & & & \\
\hline High school principal & & & \\
\hline High school guidance counselor & & & & \\
\hline Athletic coach & & & \\
\hline High school friend & & & \\
\hline College friend & & & \\
\hline Parents/Guardians & & & \\
\hline Brother or Sister & & & \\
\hline $\begin{array}{l}\text { Relatives who are not my } \\
\text { parents or sibling }\end{array}$ & & & \\
\hline Personal interests or hobbies & & & \\
\hline Other: & & & \\
\hline
\end{tabular}




\section{Engineering/Technology Teacher Education Recruitment Survey}

Directions: Aside from being your future career choice, which of the following factors are most influential in your continuance in the Engineering/Technology Teacher Education Major? Please indicate, by checking the appropriate box below, to what degree each of the following items influence your decision to continue in the Engineering/Technology Teacher Education Program.

\begin{tabular}{|l|l|l|l|l|}
\hline \multicolumn{1}{|c|}{$\begin{array}{c}\text { Which factors encourage } \\
\text { you }\end{array}$} & $\begin{array}{c}\text { Absolutely } \\
\text { No } \\
\text { Influence }\end{array}$ & $\begin{array}{c}\text { Somewhat } \\
\text { Influenced }\end{array}$ & $\begin{array}{c}\text { Highly } \\
\text { Influenced }\end{array}$ & $\begin{array}{c}\text { Strongly } \\
\text { Influenced }\end{array}$ \\
\hline Involvement in TECA & & & & \\
\hline Small class sizes & & & & \\
\hline $\begin{array}{l}\text { Relationships with other } \\
\text { students in the major }\end{array}$ & & & & \\
\hline $\begin{array}{l}\text { Positive job outlook (high } \\
\text { placement rates) }\end{array}$ & & & & \\
\hline $\begin{array}{l}\text { Positive relationships with } \\
\text { Engineering/ Technology } \\
\text { Teacher Education faculty }\end{array}$ & & & & \\
\hline $\begin{array}{l}\text { One-on-one attention from } \\
\text { university faculty }\end{array}$ & & & & \\
\hline $\begin{array}{l}\text { National reputations of } \\
\text { university faculty and } \\
\text { program }\end{array}$ & & & & \\
\hline $\begin{array}{l}\text { Laboratory and/or classroom } \\
\text { facilities }\end{array}$ & & & & \\
\hline Interest in course content & & & & \\
\hline Success in course work & & & & \\
\hline Other: & & & & \\
\hline
\end{tabular}




\section{$\underline{\text { References }}$}

1. Daugherty, M. (1998). A recruitment crisis: Strategies for affecting change. The Technology Teacher, 57(7), 21-26.

2. Daugherty, M., \& Boser, R. (1993). The recruitment imperative: Replacement of displacement. The Technology Teacher, 52(7), 31-32.

3. Fitzgerald, M. (2008). Personal Communication, January 14, 2008.

4. Gray, M. \& Daugherty, M. (2004). Factors that influence students to enroll in technology education programs. Journal of Technology Education, 19(2), 5-19.

5. Karnes, R. \& Starkweather, K. (1999). Technology Education in Prospect: Perceptions, Change, and the Survival of the Profession. Journal of Technology Studies, 15(1) 27-28.

6. Litowitz, L. S. (1998). Technology education teacher demand and alternative route licensure. The Technology Teacher, 57(5), 23-28.

7. National Academy of Engineering. (2004). The engineer of 2020: Visions of engineering in the new century. The National Academies Press. (pp. 47-57).

8. National Science Foundation (2006). Extraordinary Women Engineers: Final Report. Grant No. EEC-0438810 (pp3-14)

9. Schmidt, K. Editor. (2007) Industrial Teacher Education Directory. Department of Technology Education, Illinois State University, Normal, Illinois: CTTE and NAITTE.

10. Shanahan, B. (2006). The Secrets to Increasing Females in Technology, 66(2), 22-24.

11. Volk, K. S. (1993). Enrollment trends in industrial arts/technology education teacher education from 1970-1990. Journal of Technology Education, 4(2), 46-59.

12. Weston, S. (1997).Teacher shortage-supply and demand. The Technology Teacher, 57(1), 6-9.

13. Wright, M \& Custer, R. (1998). Why They Want to Teach: Factors Influencing Students to Become Technology Education Teachers. Journal of Technology Education, 10(1) 58-70. 